\title{
A REEVALUATION OF THE INTERNATIONAL PATENT CONVENTION
}

\author{
HeInRich Kronstein* and Irene Till $\dagger$
}

I

With the end of World War II all of the established institutions and practices involved in international relations have been subjected to new scrutiny. Are patents involved in this ferment? Is there need for a "study of the present convention on patents" as recently proposed? ${ }^{1}$

The patent field is one of the very few in which by the end of the last century the interests of the nations were already coordinated by international treaty. This was accomplished in the "International Convention for the Protection of Industrial Property," signed March 20, I883. ${ }^{2}$ This agreement has recently been termed "the most perfect example of a multilateral convention affecting economic matters."3 Briefly, it binds its members to give to all nationals of member countries: (I) the same treatment accorded their own nationals; (2) a priority period of one year to the applicant in one country for his filing of applications in all other member countries without being exposed to objections based on prior publication, patent application, or use; (3) a patent independent, in time and validity, from patents granted in other countries, particularly in the country where the first application was filed." The parties to the convention agree that a patentee may import goods into their countries without entailing forfeiture of his patent; and they also bind themselves not to issue compulsory licenses for failure to use the patent during the first three years. ${ }^{5}$

The member countries constitute themselves into a "Union for the Protection of Industrial Property," but there is no enforcement machinery. Reliance is placed

- Dr.Jur. 1924, University of Berlin; LL.B. I939, Columbia University; S.J.D. 1942, Georgetown University. Professor of Law, Georgetown University.

+Ph.D. 1937, Columbia University. Formerly Adviser on Industrial Organizations, Foreign Economic Administration.

${ }^{2}$ Charter for the International Trade Organization of the United Nations, Art. 4I (b), as drafted at the London Meeting, Oct. 15,1946 , by the Preparatory Committee of the International Conference on Trade and Employment (U. S. Dep't State, Dec. 1946).

${ }^{2}$ Report of the Commissioners Appointed to Revise the Statutes Relating to Patents, Trade and Other Marks and Trade and Commercial. Names under Act of Congress Approved June 4 , 18988,146 et seq. (1902). The convention was concluded at Paris on March 20, 1883 . It was revised at Brussels on Dec. I4, 1900, at Washington on June 2, 1911, at The Hague on Nov. 6, 1925, and at London on June 8, 1934 .

${ }^{3}$ National Foreign Trade Council, Inc., Comments on the Revised Charter for an International Trade Organization in Terdis of Foreign Economic Policy, Presented at Public Hearings Before an Interdepartmental Commitiee (Nov. 21, 1947). Hearings before the Senate Committee on Finance on Trade Agreements System and Proposed International Trade Organization Charter, Pt. II, 280th Cong., Ist Sess. 997 (1947).

- International Convention for Protection of Industrial Property, Arts. II, IV.

IId., Art. V. 
upon adherence by the members to their promises, and the effectiveness of general diplomatic representations in the event of violations. The office of the Union-the International Bureau for the Protection of Industrial Property-is limited to the function of collecting and publishing information. ${ }^{6}$

This article deals with the background and with the intended as well as the actual economic consequences of the Union. Recent writings and discussions of patent experts deal largely with judicial interpretations of legal rules of the convention. ${ }^{7}$ Certainly the legalistic wording of the treaty does little to suggest anything else. In fact, however, in the building of the Union all vital issues of the modern international patent system have been decided. The convention-and the practices developed under it-are basic to the whole structure of the pre-World War II policy of restriction of economic development in the less industrialized countries and monopolization or cartelization in the more industrialized ones.

\section{II}

The United States entered the Union in $18877^{8}$ Germany, the last industrial power to join, did so on May Io, Igor. ${ }^{9}$ As often happens in the history of treaties, the actual decisions were reached before the first country signed. The creative period of the Union was between 1872 and 1881 . During this period the negotiations on the international patent convention were the battlefield for three opposing philosophies: (r) the anti-patent movement, aimed at the destruction of the patent system; (2) the recognition of patents as private property; (3) the recognition of patents as an instrument of public policy. Certainly the issue of patents versus no-patents had to be disposed of first. The fight on this point marked the first battle between the United States and the newly organized Germany of Bismarck.

The initial invitation for an international conference on patent rights came from the Austrian Government in $1872 .^{10}$ The invitation specifically stated, however, that the suggestion came from the United States:

... following a suggestion of the Government of the United States of America, the General Direction of the Universal Exposition intends to unite with the Exposition an International Congress, which shall discuss the question of patent right; should this discussion, as may be foreseen, induce a vote in favor of Patent protection, it will then be the task of this Congress, on the basis of the experience of various countries and the materials collected, to proceed to a declaration of fundamental principles for an International Reform of Patent Legislation. ${ }^{11}$

${ }^{\circ} I d$., Art. VI.

${ }^{7}$ 5I Transactions of [British] Institute of Chartered Patent Agents 224 (1942-45).

- Approved by the President March 29, 1887; proclaimed June II, I887.

- Festanbe des Deutschen Vereins für den Schutz des Gewerblichen Eigentums Der Anschluss des Deutschen Reichs an die INTERnational Union für Gewerblichen Rechtsschutz 43 (1902).

${ }^{10}$ Document entitled Universal Exhibition 1873 in Vienna, International Congress for the Consideration of Patent Protection (National Archives, Washington, D. C., Records of the Office of the Sccretary of the Interior, Patents and Miscellaneous Division, Letters Received Concerning Patents (Box 82)).

${ }^{11}$ Id. at 3 . 
American leadership in the conference was eagerly anticipated by the United States Commissioner of Patents. He wrote to the Secretary of the Interior on May 29, 1873:

I regard the patent congress to be held at Vienna of the very greatest importance and the world looks to this government for the presentation of matters for consideration and discussion. If the American system can be properly presented before that Congress, discreetly and cautiously sustained with facts and figures, I feel confident that the best results can be expected..$^{12}$

The very fact of American parentage elevated the prestige of the conference. The proposal for international patent protection did not come from the semi-feudal country of Austria, conspicuously lacking in industrial development; it came from the United States, already at the forefront industrially and with the strongest patent system in the world.

The invitation stated the issue between the patent and the anti-patent forces in forthright manner:

There exists today an antipatent movement which since 1860 has extended too far and the causes of which movement bear, in part at least, too much upon views which are generally acknowledged by the economical progress of our age, to justify at this time as hitherto a partial solution of that problem. The complete abolition of all Patents for inventions, such is the motto of this movement; Patent protection, the maintenance and improvement of the existing Patent law, if possible in simple form, and by international agreement: such is the watchword of the other. The present condition of Patent legislation in the most enlightened and progressive countries shows on which side the majority stands; with the exception of Switzerland and with her, Holland, which recently abolished her Patent law, the legislation of all the other Industrial States today recognizes the protection of Patents as a necessity..$^{13}$

Germany, as the leader of the anti-patent movement, is not mentioned in the invitation, reference being made only to Holland and Switzerland. There is no doubt, however, that it was the larger country which the organizers of the conference really had in mind. As early as I 868 Bismarck, as Chancellor of the North German Federation, had gone on record as hostile to any form of patent protection. ${ }^{14}$ On May Io, 1872 , the German Parliament discussed, for the first time in the history of the German Reich, the patent problem. ${ }^{15}$ There the position of Bismarck was made even clearer. His representative announced that it would not be undesirable "if the Parliament would use the opportunity of the discussion to express itself in favor of the full abolition of patent protection"; ${ }^{16}$ in Bismarck's opinion, the

${ }^{12}$ Letter of Commissioner Leggett to C. Delano, Secretary of the Interior (National Archives, Washington, D. C., Records of the Office of the Secretary of the Interior, Patents and Miscellaneous Division, Letters Received Concerning Patents (Box 82)).

${ }^{13}$ Universal Exhibition ${ }_{1873}$ in Vienna, International Congress for the Consideration of Patent Protection, cited supra, note ro, at 2.

2"I Jahrbuch fuer Gesetzgebung, Verwaltung und Rechtspflege des Deutschen Reichs (Holtendorf), 258, 259 (1872).

${ }^{16}$ I Stenographische Berichte, Retchstag I. Legislaturpertode 3. Session 304 (1872).

${ }^{10}$ III Stenographische Bertchte, Rieichstac I. Legislaturperiode 3. Session ig8, n. 2.4̨8 (i872). 
example of Holland deserved to be copied. ${ }^{17}$ However, it was pointed out to the Parliament that public opinion in Germany might be unprepared for the step:

... since only people who have a private interest in patent protection can express their views in public... The Society of German Engineers has repeatedly and actively come out in favor of patent protection. However, not all engineers share this opinion; only considerations for influential interests prevent them from expressing their opinion in public. ${ }^{18}$

Thus, in the summer of 1872 , the issue was joined. The organizers of the conference were fully aware that, in a competitive business economy, the world could not live half with patents and half without patents. The invitation to the conference sets forth the interdependence among national patent systems in the following classical statement:

We live no longer in the day of Industrial action, which is strictly confined and is removed from foreign competition, and where slow communication prevents or delays the utilization of inventions. We live at a time of liberal Customs policy; Steam and Electricity have newly united once isolated seats of industry in a way undreamt of; and the mutual exchange of goods shows today a magnitude which a generation ago one could not have imagined. Under such altered relations the Patent granted for an invention in one country becomes in fact a restriction unprofitable and obstructive, if the same invention without limitation or increase in price, becomes in an adjoining country common property. The artisan who in the one country must work with the auxiliary material there patented and therefore dearer in price, will suffer an essential injury as soon as the same material is produced in the other country, not only without restriction, but with a damaging competition. Moreover a continuance of the hitherto antagonistic views and measures would scarcely conduce to the preservation of general harmony; and if, for example, Patent protection were maintained in one country, so as to attract thereby skilled operatives from another, then the danger of disturbance of the International industrial balance might readily be apprehended. Such and similar inconveniences can only be met by the common action of all civilized States, disposed to the maintenance of Patent protection. ${ }^{19}$

The American delegation to the Vienna conference was an able one. The Assistant Commissioner of Patents, J. M. Thacher, headed the group; ${ }^{20}$ his experience and knowledge of the United States patent system gave him a leading role in the negotiations. ${ }^{21}$ Unlike many American delegations to international conferences, it was also well prepared. M. D. Leggett, Commissioner of Patents, recommended that our representative should:

${ }^{17}$ Ibid.

${ }^{18}$ Ibid.

${ }^{20}$ Universal Exhibition 1873 in Vienna, International Congress for the Consideration of Patent Protection, cited supra, note 10 , at 2.

${ }^{20}$ Report of the Commissioners Appointed to Revise the Statutes Relating to Patents, Trade and Other Marks and Trade and Commercial Names under Act of Congress Approved June 4, 1898 7 (1902).

21 Thacher was described by the Commissioner of Patents, who suggested his appointment, as a "man of thorough education, good address, sound judgment and well versed in patent law and the prospects of invention in the useful arts." Letter of Leggett, June 7, 1873 , Records of the Secretary of the Interior. (National Archives, Washington, D. C.) 
... present and explain the American Patent System, calling special attention tor. The justice and expedience of granting patents for new and useful inventions to original inventors, and to such only.

2. The importance of thorough preliminary Offcial examination to determine the questions of novelty.

3. The influence of our Patent System upon the industrial interests of the country.

4. The liberal spirit of our Patent Laws towards the citizens of other countries.

In addition, he should press as a matter of justice between nations, that

I. Mere importers should not receive patents.

2. That patents granted in one country to citizens of another, should not be subject to such restrictions as to time and place of manufacture, as to render such patents comparatively worthless.

He of course should be instructed to make no concessions that can be interpreted as abandoning any of the essential features of our system.22

Thacher's own report indicates the tenor of the conference. He said:

It was the general, I may say universally expressed, opinion in the congress at Vienna that in order to secure the advancement of the mechanic arts in their own countries and to prevent the emigration of their most skilled artisans, it was necessary to secure a reform in European patent legislation.

Count Andrassy, the premier of the Austrian Government, put it in a very few words during an interview with the permanent committee when he said:

"I look to England and I look to America, and I find that they are the foremost countries of the world in manufactures. I find also, upon examining their laws, that they have the best patent systems in the world.

"Putting these two facts together, I conclude that the one is dependent upon the other, and therefore I am in favor of a thorough reorganization and revision of the patent laws of Austria."23

The Vienna conference made this general attitude manifest in its set of resolutions. It declared that the existence of a patent law was a requirement "of all civilized nations"; and foresaw "great injury ... inflicted upon countries which have no rational patent laws by the native inventive talent emigrating to more congenial countries where their labor is legally protected." ${ }^{24}$ The conference endorsed the "English, American, and Belgian patent laws, and the draft of a patent law prepared for Germany by the society of German engineers" ${ }^{25}$ (Bismarck's opponents!). One small bone was thrown to the opponents of an air-tight patent system. A recommendation provided:

It is advisable to establish legal rules, according to which the patentee may be induced, in cases in which the public interest should require it, to allow the use of his invention to all suitable applicants, for an adequate compensation. ${ }^{26}$

${ }^{23}$ Letter of Leggett to the Acting Secretary of Interior, June 30,1873 , Records of the Secretary of the Interior (National Archives, Washington, D. C.)

${ }^{23}$ See note 20, supra.

34 Introduction to Resolutions and I (f) of Resolutions of Vienna, reprinted in I Foreiç RELATIONS OF THE UNITED States $75(1873-74)$.

${ }^{25} \mathrm{Id}$. at II (g) of Resolutions of Vienna.

${ }^{20} \mathrm{Id}$. at II (f) of Resolutions of Vienna. 
Later this resolution was described by one of its drafters as mere propaganda against the enemies of patents. ${ }^{27}$

Thus the Vienna conference was an outstanding American victory, won by a purposeful policy. It is an anticlimax to read in the interdepartmental correspondence that at the last moment the State Department lacked sufficient funds to send an American representative unless he could personally assume a substantial share of the cost of the trip. ${ }^{28}$

Bismarck immediately found himself confronted with a combined attack from within and without Germany. The Society of German Engineers was already hard at work; and now it had the added prestige of powerful support from abroad. ${ }^{20}$ Bismarck was forced to retreat. In 1876 he called a committee of experts to study the patent situation..$^{30}$ In February, 1877 , he submitted a patent bill to Parliament. ${ }^{31}$ The eminent Charles Lyon-Caen made the following observations on this develop. ment:

A complete understanding of this important bill depends on an understanding of the principles which motivate the government. The government has never admitted that the institution of patents has anything to do with its ideas of justice. The government does not even seem to be convinced that the patent system actually favors the progress of industry. It suggested the passing of the bill only because Germany cannot stand isolated in the middle of all great nations which have patent statutes. In fact, the government in its memorandum explaining the new step stated: "Germany, resolved to suppress the patent system, could effectively take steps to this end only if other countries were expected to follow. This is, however, more than doubtful; and such a step would certainly result in the complete isolation of Germany for many years."32

III

The American victory in the issue of patent versus no-patent, decisive as it was, merely transferred the battlefront to the next stage. This was the issue of patents as private property rights as against patents as instrument of public policy. The impending struggle was foreseen in the American-Austrian discussions of I872. The American Government opened the dispute by complaining against the Austrian principle providing for forfeiture of patent rights if local manufacturing were not begun within one year from the grant of the patent. Here was a clear statement of the issue. John Jay, then American Ambassador in Vienna, pointed out to the Austrian Minister for Foreign Affairs on March 17, 1872:

${ }^{27}$ In the Convention of Paris on Sept. II, 1878 , Dr. Wirth of Frankfurt declared that the Vienna Resolution in regard to compulsory licenses was only a concession made to the cnemies of the Patent System. Journat Officiel de la Republieue Francaise gi87 (i878).

${ }^{28}$ On June 5, 1873 , Hamilton Fish, Secretary of State, wrote to Delano, Secretary of the Interior: "You are aware that there is no appropriation at the disposal of this Department wherewith to pay more than the reasonable expenses of the person who may be selected." (National Archives, Washington, D. C.)

${ }^{20}$ Reference is made to II $(g)$ of the Resolutions of Vienna.

${ }^{\text {so }}$ Doc. No. 70 of Federal Council (Bundesrat) Sess. of 1876 , reprinted in II DrucksacheN To DEN Verhandlungen des Bundesrats des Deutschen Reichs 64.

${ }^{32} 7$ Bulletin de la Société de la Legislation Comparée 98, 102 (1877-78).

2 Id. at 98 . 
It has been suggested that the differences in the statutes of different countries, in regard to patents, may be generally traced to a difference in the general view taken of the character and position of the patentee; whether he is looked upon as a monopolist who owes all his rights to exceptional law, and who must be jealously watched and severely restricted; or whether he is regarded as a public benefactor, who is to be tenderly and kindly treated. The legislation of Congress has inclined more and more to the latter view; and, while adopting, as the true principle, that the inventor and public are both to be treated rationally, justly, and impartially, its tendency has been to give more and more liberally encouragement and assistance to useful inventors. ${ }^{33}$

John Jay frankly assured Count Andrassy that the President would "cordially embrace this opportunity of cementing the friendship of the two countries and of advancing their common interests by a generous and harmonious policy"34_if only Austria would modify its patent law in conformity with the United States statute and would agree to full reciprocity in matters of patents between the two countries. ${ }^{35}$

This American view toward patents was novel. It stemmed from an actual faith that, in a competitive economy, patents under the control of private owners would not be subjected to abuse. ${ }^{36}$ The files of the United States Patent Office contain a constant reiteration of this theme; they reveal an absolute faith in the beneficent effects of an uncontrolled patent system. ${ }^{37}$ It was precisely this freedom, it was believed, which accounted for the rapid technological advance in the United States. ${ }^{38}$ In consequence, the Patent Office violently opposed any kind of govern-

${ }^{33}$ John Jay's note to the Imperial and Royal Minister for Foreign Affairs of March 17,1872 , ForEIGN Rezations of the United States 50-5I (1872).

"Id. at 52 .

sibid.

${ }^{30}$ Here and there some doubts were raised in the faith. At a Senate patent hearing in 1877 , Senator Wasleigh said bluntly, "While a man has a right to put his horse into his own barn, and not use it himself, he has no right to lock up his invention and let nobody use it. It is his duty to let his invention go out to the world." The reply of A. H. Walker, patent attorney, is a statement of the dominant American position:

"He has no such duty with reference to the period of his monopoly at all. The only duty he has is to spread the description of the invention on the records of the Patent Office, so that after the monopoly has expired, whether it be in fourteen, or seventeen, or twenty-one years, it will be free to the world. He has no duty to publish that invention, or introduce it during the life of the monopoly; and if he chooses to let it die as useless, there is no law or reason why he shall not be permitted to do so. ... As I understand the theory of the law, it is his absoltute property during the life of the monopoly and is not qualified. Indeed, that is the language of the Constitution itself, viz., that the right is cxclusive. . . ." Argtments before the Committee on Patents of the U. S. Senate and House of Representatives, Mrsc. Doc. No. 50, 45th Cong., 2d Sess. 36 (1878).

${ }^{37}$ These files are in the National Archives, Washington, D. C.

${ }^{38}$ At the 1877 patent hearing, J. J. Storrow, patent attorney, testified:

"Sir William Thomson went home from our Centennial Exhibition, and just as he got home he appeared before the British Association, before the section of steam-engineering, of which he is the president, and, in giving them an account of what he had seen in this country, he called their attention very sharply to the effect of patent laws on the improvement of labor-saving machinery. He told them that unless the countries of Europe speedily amended their patent laws, and unless they amended them in a contrary direction to the bill pending in Parliament, they must understand that they would lose their manufacturing supremacy and that Amercia would take it from them. Another gentleman (Mr. St. John V. Day), discussing the pending patent bill quite in detail at the same meeting, declared that, unless they improved their system so as to give more general encouragement to inventors, they would lose their manufacturing supremacy, and with that would give up their commercial supremacy, for that depended on their ability to cheaply supply neutral markets; and, after an interesting discussion, the association resolved that a committee be appointed to procure changes in the law, so that it might be 
mental interference-whether against foreign inventors in this country ${ }^{30}$ or American inventors abroad. At every opportunity in the correspondence of the patent commissioners with foreign patent offices-through State Department channels or in direct negotiation-the view is developed that only international cooperation and mutual recognition of private property in patents can serve the final aim of the highest technological advance everywhere. The constant reiteration of this gospel by the most highly industrialized country in the world was bound to have an enormous effect.

But such an approach was in direct conflict with established tradition abroad. The American philosophy was genuinely new. True, the speeches of the French Revolution were aflame with this doctrine; Mirabeau exultantly speaks of inventions and patents as private property equal to any other form of private property. But, in fact, the French never drew the logical conclusion from these theories. ${ }^{40}$ The patent statute of France after the Revolution provided that patents should be forfeited in the event that patented goods were imported into France. ${ }^{41}$ Such a provision was a clear denial of the private property aspect of a patent, and made patents an instrument of public policy to bring manufacturing plants into France. This law still existed at the time of the Vienna conference.

The English patent statute of 1623 had the same purpose. Though usually called the "mother of our patent law,"." it differed markedly in aim, method, and field of coverage from our modern patent law. The English statute was a device for bringing new trades into England. Inventions were not new discoveries; trades and skills were "inventions" and patentable if their appearance in England was new. The English documents are replete with instances of the granting of patents for trades imported from the continent. ${ }^{43}$ Nor did English patents cover a strictly

more favorable to inventors. The consequence has been, that only last Junc ( 1877 ) the government withdrew their pending bill."

Storrow goes on to quote approvingly the remarks of Hulse, English judge of textile machincry at the Centennial: "As regards extent of invention and ingenuity, the United States was far ahead of other nations. . . The extraordinary extent of ingenuity and invention existing in the United Statcs, and manifested throughout the exhibition, I attribute to the natural aptitude of the pcople, fostered and stimulated by an admirable patent law and system, and to the appreciation of inventions by the people generally." Arguments before the Committee on Patents, Misc. Doc. No. 50, 45th Cong., 2d Sess. 318 (1878).

${ }^{38}$ On Nov. $\cdot 8,1854$, Commissioner E. Mason protested to R. McClelland about a suspicion of the American Consul in Paris that foreign applications are handled with bias. He gocs on to say, "As an evidence of the truth and sincerity of those statements 1 refer to pages 16,17 , and 18 of the last Patent Office Reports in which the most unequivocal recommendations will be found in favor of abolishing all discriminations as against foreign applicants and of encouraging inventors from all quarters of the world to place in this Office the Representatives of their genius." (National Archives, Washington, D. C.)

1024 ARchives ParLementaires de 1787 ^ 1799636.

1 Id. at 655 .

12 An interesting limitation on this often repeated statement is to be found in the Vienna invitation: "As an object of legislation, its [the patent's] origin extends back to foreign countries as for instance in Great Britain the right of the Crown to the concession of Patents for invention was cstablished by the Acts of Parliament of 1623 . But as a matter of controversy, it is scarcely twenty years old, yet notwithstanding its recent date, it already possesses its peculiar history:"

${ }^{43}$ Hulme, The History of the Patent System under the Prerogative and at Common Latv, II Lnw Q. REv. I4I, I45 (I896). 
limited process or product. In fact, just the opposite was true. The patent was granted before the governmental authority even obtained any specification. Not until 1780 did specification become a precondition for the grant of patents; and not until then did the concept of novelty have importance in the field of patents. Thus in the early history of Britain the issuance of a patent was essentially a political; expedient; a temporary monopoly was justified if it brought new trades and skills to the island. ${ }^{44}$

Obviously, the American view expressed in John Jay's letter had nothing in common with the traditional European approach. The question for the Germans -once they had abandoned their original hostility to the patent system-was which view they would adopt. Quite naturally they turned to the early English position. They were newcomers in the industrial hierarchy; they had all of the anti-monopolistic attitudes of the upstart competitor. They immediately adopted the position that patents should not be granted as a matter of right to every inventor, but should be permitted only in those fields in which the public interest justified the grant. Nor were they prepared to look upon patents as private property, to be granted to outsiders without limitation. Patents were a qualified right, subject to governmental interference in the interest of the nation.

Bismarck's committee of experts meeting in 1876 was fully dominated by this older view. ${ }^{45}$ One of its members was founder of the Siemens Combine. He was already concerned about the possibility that American Edison and British Thomson-Houston would take out many patents in Germany-before the German firms could develop their own research. He said bluntly:

You might consider a rule that patentees are bound to grant licenses as an interference with the right of the inventor; but such a rule is absolutely necessary. The interests of [German] industries require that licenses be made available as a matter of right. Today industry is developing rapidly; and as a result monopolization of inventions and abuse of patent rights will inevitably expose large segments of industry to serious injury. The government must protect industry against these dangers. From abroad another danger may arise. Inventive work is far more developed in England, United States and France than in Germany. Up to the present the number of patents taken out in Germany by foreigners has been small because the scope of protection given to the inventor has been insufficient. New legislation will lead to a substantial increase of foreign patentees. We shall experience a wave of foreign-particularly Americanpatent applications. These patents will not be taken out in order to protect industrial plants established or to be established in Germany; they will be taken out to monopolize production abroad. These articles will be imported into this country.

Such a danger must be met. It is not enough to provide that foreign patentees be required to submit "evidence" that they have established a plant in Germany. Such

4The Statute of Monopolies in 1623 provided that letters patent could be granted for the "sole working or making of any manner of new manufactures within this realm"; and subsequent court decisions construed this provision to include protection to imported technologies as well as genuinely new inventions.

\&5 "Protokolle" of the Committee of Experts on Patent Law (Patent Enquete), Drucksache No. 70 des Bundesrats Session von 1876 . II Drucksachen in DeN Verfandzungen des Bundesrats des Deutschen Reichs, Session No. 70, 9 (1876). 
evidence may be mere "shadow"; they can merely keep a small domestic production going to maintain their patents. The French have an effective weapon-a rule that patents shall be forfeited if an inventor imports or permits others to import patented goods. However, the French method is inconvenient to trade interests, and would meet serious objection here. The requirement of actual manufacture under the patent would be excellent if the patentee were forced to show production in such quantities that domestic needs are actually met.

The same end can best be achieved by requiring that licenses be granted. The administration of this plan may be difficult. But the administrative agencies and the courts should be able to meet the difficulties and to come to a modus vivendi. Royalties should be based on the importance of the inventions. In the U. S. today there is what amounts to a compulsory license feature since the courts usually dismiss suits of patentces for infringement if the defendant can show that he has offered reasonable royalty but was refused a license. ${ }^{46}$

Siemens ended with the proposal that licenses of right should be made available at the end of the fifth year of patent protection. He felt that any other arrangement would be inconsistent with the public interest.

This same meeting was attended by one of the founders of the Hoechst Farbwerke, predecessor of I. G. Farben. Bruening took the position that the entire chemical industry should lie outside of patent protection. He said:

In the chemical industry the most harmful effects of patents are made clearly cvident. Patents in France and England prevented the development of new chemical branches such as the manufacturing of aniline and alizarin dyes. Invention in chemical technology consists largely in an idea, and the practical exploitation of this idea usually involves enormous difficulties. In England and France patents for the manufacturing of aniline and alizarin dyes have been issued to the inventors who have not succeeded in the effective exploitation of their invention. In those countries monopolistic organizations came into existence which could not themselves produce and their major function was to prevent the development of other plants. In Germany, however, the chemical industry was able to expand because no patent protection prevented the free play of competition. ${ }^{47}$

In the meantime the American view of patents as private property came into popularity in other countries. Between 1873, the year of the Vienna conference, and 1878 , the year of the Paris convention, the American view prevailed in all

'Siemens' last sentence seems in direct conflict with established American law and judicial practice.

47 Bruening was not alone in his application of the public instrument rule for the chemical industry. While he did not prevail in Germany against Duisberg, the chief promoter of the patent movement in Germany's chemical industry, the Swiss Chemical Industrie succecded for some time in making this view the official Swiss position. At the last moment, before the international convention went down the line in favor of the unlimited patentability of chemical inventions at the Paris convention in 1878 , the Swiss representative pointed out:

"The grant of chemical patents means the establishment of a privilege which is actually a monopoly for a temporary period. In France a patent was granted to the firm of Renard Freres covering the field of aniline. The French industrialists who later succeeded in manufacturing this product commercially had no choice but to become refugees in Switzerland in order to produce. France rendered a great service to Switzerland in making this gift." Journal. Officiel de IA RepubliQue Francaise 9152 (1878). It is interesting to note that Renard Freres remained obscure, while the Basel dyestuffs producers developed into a world power in the chemical field.

${ }^{68}$ Mecting of Sept. 6, 1878, Journal Officiel de la Republique Francaise gi5i (1878). 
European countries except Germany, Switzerland, and Holland. ${ }^{48}$ In consequence, the following formula was submitted at the Paris meeting:

The right of inventors and industrial creators in their own work or the right of the industrialists in their trademarks is a property right which has its basis in natural law. The law enacted by each nation does not create these rights but only regulates them.

The Swiss delegation joined issue by offering a counter motion:

The rights of the inventor and creative worker are a creation of equitable and useful principles of the law of each nation which should reconcile this right of the inventor, based on the grant of a temporary monopoly, with the rights of society. ${ }^{49}$

The Swiss motion was voted down and the "property" motion won, though the clause "which has its basis in natural law" was eliminated.

Once an international convention declared inventions and patents a type of private property, it was only logical to grant to the "owners" of such property equal protection under the law, whatever their nationality might be. In the philosophy prevailing at the end of the nineteenth century, no principle was more sacred than the mutual protection of the vested interests of private property. Once patents were recognized as a type of private property there was no possible justification for the continuance of the forfeiture penalty for importation of patented goods or for the harsh rules respecting working clauses. The French system broke down almost immediately, and the working clauses gradually fell into disuse. The priority rule made its obsequious entry as a simple convenience for the property owner.

Germany continued to remain outside of the convention during the Eighties and mid-Nineties. ${ }^{50}$ In that country the scope of the patent grant was limited in the interest of encouraging further invention, and patents were subjected to compulsory licensing. But in 1897 , at the Brussels convention, Germany appeared and prepared the way for her retreat. ${ }^{51}$ One of her major concerns was the elimination of the working clause. 52 To this end she won the ardent support of the United States. ${ }^{\mathrm{63}}$

\footnotetext{
10 Ibid.

${ }^{\circ}$ Festgabe des Deutschen Vereins für deN Schultz des Gewerblichen Eigentums: Der ANschluss des Deutschen Reichs an die International. Unon 901 (ig02).

"2 Report of the U. S. Delegates to the Brussels Conference of I897, in REPORT of THE Commisstoners Appointed to Revise the Statutes Relating to Patents, Trade and Otmer Marzs, and Trade and Commercial Names under Act of Congress Approved JUNE 4, 1898 r92 (1902).

${ }^{82}$ The statement of the German delegates contained the following: "The Imperial Government considers that, in requiring the working of the patent under pain of forfeiture, obligations at the same time onerous and in part impossible to realize are imposed on the inventor who has demanded and obtained a patent in a certain number of States, and that without real profit to industry in general. To restrain the obligation of working is, then, in its eyes one of the ends to which the efforts for an international understanding should principally be directed. It is from this point of view that it appears to be desirable to establish an article by virtue of which the actual working in one of the contracting States shall remove in all the other contracting States any prejudice resulting from lack of working." Id. at 2 ro.

${ }^{6}$ The Americans took the position that "abolition of working altogether would be an act of reciprocity toward the United States, which now grants unrestricted patents to citizens of countries which impose such a condition." Id. at 201. Opposition to the working clause has always been maintained
} 
In Igor Germany joined the Union. ${ }^{54}$ In a short time she became, along with the United States, the most ardent defender of the Union. In the later conferences the two countries worked together effectively to strengthen the protections accorded the patentee. ${ }^{55}$ In fact, the International Patent Convention can now almost be referred to as an American-German patent alliance..$^{\text {so }}$

IV

How could this situation come about? How was it possible that an international agreement on patents could be arrived at between industrialized countries and those on the make?

The answer lies primarily in three factors: (I) the transition from free trade to high tariff, accomplished by Germany in 1879 and by other European countries shortly thereafter; (2) the domestic patent agreements in the German chemical industry which had wide effects throughout the world; and (3) the development of the American-German patent cartels.

Quite rightly the Austrian-American invitation to the Vienna conference referred to the Seventies as a "time of liberal customs policy." 57 But when Germany joined the Union the change from free trade to tariff protection had already taken place. As a result, the rule of the Union prohibiting forfeiture of patents if goods were imported no longer had any significance. A high tariff could-and did-have the same effect as forfeiture in the case of non-use; indirectly imports were prohibited, and without domestic production no exploitation of the patent remained possible in that country.

The whole doctrine of the "equality of foreigners with citizens" in regard to patents also came to have a very different significance when a nation was behind a tariff barricade. To be sure, the formal legal position of national and foreigner remained "equal." But the national having one plant inside the tariff wall could

in the United States, and is to be found in a statement of Conway P. Coe, former U. S. Commissioner of Patents, at a House hearing in 1935 . He said: ". . . there are European countries that have a working requirement in their patent law. However, I do not think that those countries have progressed industrially as we have here. I see no reason for imposing a law of a foreign country that is backward in patent development and industrial development on a country whose industries have prospered as they have in this country. There are many people who say that the industrial supremacy, that the United States now enjoys, is attributable in no small measure to our own patent system." Hearings before the Committee on Patents on H. R. 4523, Pt. I, 74th Cong., Ist Sess. 1068 (I935).

${ }^{5}$ Festgabe des Deutschen Vereins für den Schultz des Gewerblichen Eigentums, Der Anscilluss des Deutschen Reichs an die Internatjonal Union für Gewerblichen Rechtsschutz 43 (1902).

${ }^{68}$ Commissioner Coe stated categorically in 1935 that "while the international convention for the protection of industrial property was revised in a number of points, those revisions invariably approached the American law; and every other country in the world belonging to this convention, or practically every other one, yielded its own domestic law in favor of what is apparently regarded as the superior patent laws of the United States." Hearings before the Committee on Patents on H. R. 4523, Pt. I, 74th Cong., Ist Sess. 1067, 1068 (1935).

so By 1935 the German patent structure had become such a bulwark in the protection of the rights of patentees that such $2 n$ eminent expert in this field as Lawrence Langner could seriously suggest that the German patent system had started in 1780 or 1790 . Id. at 630 .

${ }^{57}$ Document entitled Universal Exhibition 1873 in Vienna, International Congress for the Consideration of Patent Protection. (National Archives, Washington, D. C.) 
exploit his patents there and also-through exports-in those countries without tariff protection. On the other hand, a producer in a non-tariff country had to confine his activities to free-trade countries, unless he was willing to establish a plant in the country with tariff walls. As a matter of fact, without a tariff Germany could not have adopted the conditions of the patent convention unless she first relinquished her industrial ambitions. Exactly the same was true of other industrially backward countries. If they aimed to achieve an industrial position of their own, they had to combine membership in the Union with a protective tariff. The patent convention alone would have resulted in a monopolistic position for those countries which were most industrialized at the time the convention was signed.

The patent convention, combined with tariff protection for the partially industrialized countries, opened the way to two possible developments:

I. The exercise of monopoly rights for the patentee through establishment of manufacturing plants in protected countries and through exports to unprotected areas;

2. The development of cartel arrangements among producers in industrialized competing countries, themselves frequently protected by high tariffs. This was accomplished through the exchange of patent rights among these producers, under which home territory was insulated from possible competition by private agreement and backward countries were parceled out as mere marketing outlets.

It is to be noted that both of these devices have the same purpose-the limitation of competition through the exclusion of newcomers. The first guarantees price protection and the established power of a dominant unit in the industry; the second serves the same function for a multiplicity of units, each with considerable economic power and constituting a grave potential threat to the others.

The statement has been made that the enactment of a tariff statute was a precondition of Germany's participation in the international patent convention. Can we say the same in respect to cartelization and patent agreements?

At the outset the timing of the two events-Germany's entrance into the convention and the development of the patent cartel-is remarkably coincidental. This can best be indicated by reference to the German dyestuffs industry, which, between the r8go's and World War I, was the outstanding example of international monopoly based on patent rights. ${ }^{58}$ More accurately, it was monopoly over the international market exercised by a domestic cartel. It will be recalled that, during the Bismarck investigation, Bruening had given a pessimistic prediction of the consequences of an uncontrolled patent policy in the semi-industrialized German economy. But his confrere, Carl Duisberg, saw the situation in a wholly different light. He proposed to the competing dyestuffs enterprises in Germany that they form what in effect amounted to a domestic patent pool..$^{59}$ In this manner the hundreds

\footnotetext{
${ }^{68}$ Hearings before the Committee on Patents, Pt. 5, 77th Cong., 2d Sess. (1942).

Testimony of Heinrich Kronstein in Hearings before the Committee on Patents, Pt. 3, 77th Cong., $2 d$ Sess. 1270 et seq. (1942).
} 
of patents taken out by the major German firms would be pooled; new advances in the rapidly developing technology would be available to all the established units; and additional chemical research would be speeded. At the same time such a plan was calculated to freeze the existing units in their predominant position, and upstarts in the industry would effectively be excluded. This plan was adopted. As it worked out, Bruening's genuine fear that patents would be a handicap to the established units did not materialize; the effect was, on the contrary, to cement their position at the expense of newcomers. The near completion of this ambitious program coincided with Germany's entrance into the international patent convention. Its success was so great that within a short time the entire world dyestuffs market fell under the control of the German domestic cartel.

In the United States there was hardly a flutter of protest as the cartel took over the American field. In fact, this Government was so persuaded that patents were private property, to be accorded the fullest protection, that unusual steps were taken: in 1909 the United States entered a special treaty with Germany assuring her that German patentees would not be required to manufacture in this country. ${ }^{60}$ The British at least moved from the class of mere markets of the monopolist into the class of countries where the monopolist had to manufacture. In Ig07 they made a dramatic return to the pre-convention requirement of the working clause. ${ }^{61}$

In at least one specific instance Germany did use the International Patent Convention to cement its monopolistic position. This was in connection with Switzerland. At the turn of the century Switzerland loomed as a real competitive threat to Germany's dyestuffs industry; and it persistently refused to grant patents for the protection of chemical processes. In this case the United States came to the aid of Germany. At the 1897 patent convention in Brussels, the United Stateswith no dyestuffs industry of its own-proposed that Switzerland should be punished for its dereliction in the chemicals field by discriminatory measures against it. $^{62}$ Was this an expression of the American-German patent alliance? In 1904 Germany sent a virtual ultimatum to Switzerland, demanding that it grant patents on chemical processes under the patent convention's requirement of equality of treatment to nationals and foreigners. To force compliance, it threatened Switzerland with an import tariff on Swiss goods based on the total volume of its exports into Germany. ${ }^{63}$

The Swiss parliamentary debates of 1904 and 1907 give a dramatic account of the conflict. ${ }^{64}$ From one side comes the charge that Switzerland is opposed to the grant of chemical patents because she wishes to enrich her own industries by

${ }^{\circ 0}$ Id. at I294.

ex Patents and Designs Act of 1907, 7 Edw. VII, c. 29, $\$ 27(2)$.

${ }^{0}$ Reported by Mury in the Swiss Parliament (Nationalrat) on Dec. 22, 1904, XIV Amtuicues STENOGRAPHISCHES BULLETIN 6I5 (1904).

${ }^{63}$ Report of Mr. Hoffmann in the Swiss Senate (Standeret) on Dec. 17, 1906, XVI Amrzicues StenographISCHES BULIETIN 1435, I468 (1906).

ot Ibid. 
securing technological developments from abroad for nothing. The defense of those opposed to the grant of such patents is that they inevitably lead to monopoly; and the German dyestuffs industry is cited as the prime example. The very fact that the German government and the German chemical industry were demanding that Switzerland grant chemical patents was taken as an indication that the real purpose was to compel Swiss industry to join the German dyestuffs cartel. History proved that this charge was correct, for in the end the Swiss industry was compelled to become a junior partner in the German dyestuffs group.

The second development-the international patents pool-also was made possible by the international patent convention. In 1876 Siemens envisaged a situation in which the industrially weaker countries would suffer under a wave of foreign patents. This was a German problem. But between 1875 and I900 German technology, particularly in some branches of the electrical industry, developed rapidly -more rapidly than in this country. This constituted an American problem.

A tentative solution was reached even before Germany entered the patent convention. This related solely to electrical production in Germany. The German electrical firms were protected by a domestic tariff; the American companies were deeply entrenched in world trade and operated plants in Germany. In 1902 Union Elektrizitatswerke A. G., subsidiary of the American interests, and the Allgemeine Elektrizitatsgesellschaft A. G., close to the Edison Group in the bulb field since 1885, entered into a patent exchange agreement covering the German market. ${ }^{65}$ In this manner the established units guaranteed each other's positions in the German market and constructed a wall of basic patents and improvement patents to shut out the newcomer.

In r903-two years after Germany's entrance into the convention-a patents: agreement covering a wider sphere was well under way. The purpose was to eliminate competition in the home markets of the German and American producers and to effect a world division of territory between them. In December, I903, Emil Rathenau reported at a shareholders' meeting of AEG that an over-all agreement: with General Electric-newly organized in the United States-had finally been. consummated. ${ }^{6 \mathfrak{B}}$ In February, 1904, he reported that GE's exclusive territory was. the United States and Canada; AEG was given exclusive rights in Central and" Eastern Europe, Russia, and the Middle East. Special marketing arrangements forthe French and British markets were made with the GE affiliates. ${ }^{67}$

The rapidity with which the patent exchange agreement technique was seized? upon by other industries is an indication of its usefulness. The period between the first and second World Wars was characterized by incessant activity in the building: up of international patent agreements in a wide variety of industrial fields. Virtuallyevery manufacturing industry, where concentration of control existed domestically,

\footnotetext{
EE I KartellRUNDSChaU 55 (IgO3).

DI KARTELlRUNDSChaU 1242 (1903).

${ }^{\circ} 2$ KartellandoschaU 308 (1904).
} 
sent its business diplomats abroad to negotiate such agreements. ${ }^{08}$ In the United States this type of agreement had particular appeal because of the existence of the antitrust laws. As the president of Osram, the German electrical company, stated in 1932, perhaps more frankly than would his American partners:

It is of special significance that our old collaboration agreements relating to the exchange of inventions and experience which were made between the American and the other enterprises, were a good basis even as far as American law is concerned, since the reservation of certain countries for exclusive supply was based on a lawful basis. The world agreement could therefore be certain not to be attacked from the American side. The old agreements were on a sufficient basis to accomplish the aim of the distribution of the markets. ${ }^{69}$

In the United States a bald attempt to enter into agreements to restrict production, make exclusive allocations of world territory among dominant producers, and establish a structure of fixed prices, would have cut directly athwart the antitrust laws. The patent exchange agreement could be made to accomplish the same things, and it offered certain distinct advantages. The doctrine of patents as private property in the absolute sense was well established; and-if one did not go back too far-was sanctified by a number of favorable court decisions. Even in the event of an antitrust suit, much could be said in its favor. The complicated structure of patent rights and privileges in an industry created innumerable problems in the prosecution of such cases by the Government-both in the gathering and presentation of evidence and in the remedies proposed. In several instances the sheer magnitude of the economic problem proved to be too much for the courts; and they retreated into technicalities of the patent law to escape the task of a drastic reorganization of the industry. ${ }^{70}$

\section{V}

Thus the international patent convention was tightly coordinated with national tariff policies in the pre-war structure of restrictive practices in international trade. In a very real sense, it set the stage in the I880's for what came later; it made possible the restrictive patent exchange agreements with their widespread economic effects felt throughout the world. Once the convention had turned all countries in the direction of accepting patent protection and establishing international standardization of practice, it was a logical next step to press for increasing protection of the rights of the patentee. In effect, the various governments, by international agreement, abdicated control over patents in the national interest to private patentees; and the latter were quick to institute a private system of control through international patent agreements.

\footnotetext{
ab Ibid.

${ }^{\circ 0}$ Testimony of Heinrich Kronstein in Hearings before the Committee on Patents, Pt. 3, 77th Cong., $2 d$ Sess. 1318 (1942).

${ }^{{ }^{0}}$ Marcus, Patents, Antitrust Law and Antitrust Judgments Through Hartord-Empire, 34 GEo. L. J. I (1945).
} 
A realistic study of the patent convention, looking toward revision, is now long overdue. The draft of the charter for the International Trade Organization contains such a proposal; but if this agency is too long in the making, some other instrument for the investigation should be devised. A recent Argentine decree ${ }^{71}$ permitting the government to open such patents as are "responsible for unjustified price booms," indicates that the problem remains on the agenda-whether the Foreign Trade Council likes it or not. The investigation proposed should look toward the creation of international patent practices which further the exchange of information in the interest of technological expansion everywhere. Until this is done, the patent convention will remain captive to policies of trade restriction under private control.

${ }^{71}$ Neue Züricher Zeitung, June 15, r947. 